\title{
PREMATURE GRAYING OF HAIR: AN INDEPENDENT RISK MARKER FOR CORONARY ARTERY DISEASE IN SMOKERS - A RETROSPECTIVE CASE CONTROL STUDY
}

\author{
Aggarwal A ${ }^{1,}$ Srivastava $S^{2,}$ Agarwal MP ${ }^{1,}$ Dwivedi $S^{3}$
}

\begin{abstract}
BACKGROUND: Premature graying of hair as a risk marker among young smokers has a potential of identifying coronary artery disease $(C A D)$ at a very early stage. There is absence of literature that assesses premature graying of hair as an independent marker of CAD in smokers.

MATERIAL AND METHODS: The present single-centre case control study enrolled a total of 62 consecutive chronic smokers ( $\leq 45$ years) (Group I) and 60 consecutive young CAD patients ( $\leq 45$ years) who were chronic smokers (Group II). Another group comprising of 114 patients ( $\leq 45$ years) having no smoking history and no cardiac ailments either (Group III) was enrolled as control population. All subjects were males. A detailed history and clinical examination regarding conventional coronary risk factors and carotid intima media thickness was done in both groups.

RESULTS: The carotid intima media thickness, dyslipidemia and blood pressure were significantly higher in group I and II as compared to group III. When the groups were compared for graying of hair, it was found that the group II (i.e., smokers and CAD) had maximum prevalence of graying which was significantly higher than the control as well as smoker groups. The presence of premature graying of hair was associated with 3.24 times the risk of CAD on multiple logistic regression analysis.

CONCLUSION: The presence of premature graying of hair was associated with an increased risk of $C A D$ in young smokers. Premature graying of hair can be used as preliminary evidence by clinicians for classifying patients at risk for premature CAD especially in smokers.

KEYWORDS: Premature Graying, Coronary Artery Disease, Smokers
\end{abstract}

DOI: http://dx.doi.org/10.4314/ejhs.v25i2.4

\section{INTRODUCTION}

Graying of hair is a physiological process that occurs with age in both men and women. The evidence that graying of hair can occur due to oxidative stress $(1,2)$ has led to the investigation of premature graying as a risk factor for agerelated pathologies such as coronary artery disease (CAD) and osteoporosis. Oxidative stress induces ectopic differentiation of melanocytic stem cells thus reducing the stem cell pool that can replace apoptotic melanogenic melanocytes $(2,3)$. There is a rising trend of $\mathrm{CAD}$ among younger people (age $\leq 45$ years) in the Indian subcontinent. Smoking plays a dominant role in the etiopathogenesis of CAD among the young (4). One of the earliest clinical signs which may possibly help in recognizing early onset of CAD in a young smoker is the presence of premature graying of hair. Although this sign was described as early as in 80 's by Eisentein et al $(5,6)$ and later few studies from our centre have also shown similar results $(7,8)$, it has become a subject of intense research only very recently in the western world (9).

\footnotetext{
${ }^{1}$ Department of Medicine, University College of Medical Sciences \& GTB Hospital, Delhi, India

${ }^{2}$ Department of Medicine, School of Medical Sciences and Research, Sharda University, Greater Noida

${ }^{3}$ Hamdard Institute of Medical Sciences and Research, Associated HAH Centenary Hospital, Jamia Hamdard, New Delhi, India Corresponding Author: Amitesh Aggarwal, Email: dramitesh@gmail.com
} 
Although some studies have favoured premature graying of hair as a risk factor for CAD, others have not found such an association. The literature search has not revealed any study that assessed premature graying of hair as an independent marker of CAD in smokers. Thus, we need to recognize the early markers of CAD in smokers so that smokers could be persuaded to quit smoking and/or tobacco at the earliest before the disease manifests clinically.

With this background in mind, this study was planned to determine the association between premature graying of hair and CAD in smokers.

\section{MATERIAL AND METHODS}

Young patients $(\leq 45$ years of age) were recruited from the Coronary Care Unit and Outpatient Department of a tertiary care centre for this study. The study was duly approved by the Institutional Ethical Committee of the College. The period of study was from July 2011 to June 2012. The patients were recruited on consecutive basis if they fulfilled the inclusion criteria. The patients were divided into two groups. Group I of 62 consecutive young smokers without clinical evidence of CAD and group II of 60 consecutive young CAD smokers presenting with the first episode of acute coronary syndrome. A control group (Group III) comprising of 114 patients $(\leq 45$ years) was enrolled from the Outpatient Department. All subjects were males. Informed consent was obtained from all the patients before recruitment for the study. A detailed history regarding smoking habit as well as alcohol use and clinical examination for the presence of graying of hair (more than 25\% of scalp and/or beard) was carried out. Waist circumference and blood pressure were also recorded in each study subject. A comprehensive cardiac examination, electrocardiogram (ECG), fasting, and postprandial blood glucose and lipid profile were also done in both groups. Besides this, carotid intima media thickness was measured in all cases as a surrogate marker of atherosclerosis.

The diagnosis of CAD was made by the treating physician on the basis of history, clinical examination, ECG, cardiac enzymes and/or echocardiography based on the principles of standard WHO criteria (10). Hypertension was diagnosed according to JNC VIII criteria (11). Smoking was defined as continuous use of beedi, cigarette and/or any form of tobacco. Consumption of 1 gram of smokeless tobacco was taken as equivalent of one cigarette (12). A $25 \%$ or more graying of hair on scalp and/or beard on visual inspection was taken as a positive criterion for graying in the patient (9).

Dyslipidemia was defined as per national cholesterol education programme-adult treatment panel III guidelines (13). Diabetes mellitus, impaired fasting glucose (IFG) and impaired glucose tolerance (IGT) were defined as per American Diabetic Association (ADA) criteria (14).

Waist circumference was measured midway between subcostal margin and superior iliac spine in the erect position, with the abdomen relaxed the arms at the sides and the feet together. Waist $\geq 90$ $\mathrm{cm}$ in males and $\geq 80 \mathrm{~cm}$ in females was considered as evidence of central obesity (15).

Carotid-artery Intima Media Thickness (CIMT) was determined in all study subjects by a high resolution B-mode ultrasonography system (P-700, PHILIPS). Note was made regarding the location and echo characteristics of the plaque/thickening, luminal narrowing and/or calcification if any. The measurements were made in common carotid and internal carotid artery after the bulb on either side. All scanning was conducted by trained ultrasonologist who was unaware of the clinical status of the study subjects.

Exclusion criteria comprised of older patients (>45 yrs), known CAD, hypertrophic obstructive cardiomyopathy, severe left ventricular failure (Killips Class IV), advanced renal/hepatic derangements, multi organ failure, severe anaemia $(\mathrm{Hb}<6 \mathrm{~g} / \mathrm{dl})$ and who had already undergone cardiac surgery/ angioplasty.

The statistical analysis was done using SPSS software 20.0 using one way ANOVA test, Tukey's test, chi square, Fisher's exact test, multivariate logistic regression and unpaired- $t$ test. Logistic regression analysis was also performed on risk factors.

\section{RESULTS}

The mean value as well as standard error of risk factors among all subjects in each group is summarized in table 1 . 
Table 1: Comparative table of coronary risk factors among different groups along with their 'p' values

\begin{tabular}{|c|c|c|c|c|}
\hline & $\begin{array}{c}\text { Group 1 } \\
\text { (young smokers } \\
\text { without CAD) } \\
(\mathbf{n}=62)\end{array}$ & $\begin{array}{c}\text { Group 2 } \\
\text { (young smokers } \\
\text { with CAD) } \\
(\mathbf{n}=60)\end{array}$ & $\begin{array}{c}\text { Group 3 } \\
\text { (young non } \\
\text { smokers without } \\
\text { CAD) } \\
(\mathbf{n}=114)\end{array}$ & $\begin{array}{l}\text { p-value } \\
\text { (Between } \\
\text { groups as } \\
\text { specified) }\end{array}$ \\
\hline Age ( years) & $34.47 \pm 6.69$ & $38.77 \pm 5.72$ & $32.37 \pm 7.99$ & $\begin{array}{l}1 \mathrm{vs} 2=.003 \\
1 \mathrm{vs} 3=.152 \\
2 \mathrm{vs} 3=.000\end{array}$ \\
\hline SBP*( mm hg) & $119.40 \pm 2.18$ & $128.18 \pm 2.31$ & $122.06 \pm 1.64$ & $\begin{array}{l}1 \mathrm{vs} 2=.019 \\
1 \mathrm{vs} 3=.989 \\
2 \mathrm{vs} 3=.111\end{array}$ \\
\hline DBP*( mm hg) & $77.58 \pm 1.47$ & $75.67 \pm 1.56$ & $81.15 \pm 1.11$ & $\begin{array}{c}1 \mathrm{vs} 2=1.000 \\
1 \mathrm{vs} 3=.159 \\
2 \mathrm{vs} 3=.017\end{array}$ \\
\hline PP BG*( mg/dl) & $115.25 \pm 3.54$ & $141.10 \pm 6.76$ & $121.84 \pm 4.67$ & $\begin{array}{l}1 \mathrm{vs} 2=.001 \\
1 \mathrm{vs} 3=.568 \\
2 \mathrm{vs} 3=.008\end{array}$ \\
\hline $\mathrm{FBG}^{*}(\mathrm{mg} / \mathrm{dl})$ & $92.58 \pm 5.08$ & $99.20 \pm 7.40$ & $95.11 \pm 6.83$ & $\begin{array}{l}1 \mathrm{vs} 2=.328 \\
1 \mathrm{vs} 3=.792 \\
2 \mathrm{vs} 3=.592\end{array}$ \\
\hline $\mathrm{TC}^{*}(\mathrm{mg} / \mathrm{dl})$ & $150.23 \pm 5.79$ & $155.07 \pm 6.14$ & $168.75 \pm 4.36$ & $\begin{array}{c}1 \mathrm{vs} 2=1.000 \\
1 \mathrm{vs} 3=.034 \\
2 \mathrm{vs} 3=.236\end{array}$ \\
\hline $\mathrm{LDL}^{*}(\mathrm{mg} / \mathrm{dl})$ & $84.13 \pm 4.74$ & $97.50 \pm 5.03$ & $107.25 \pm 3.57$ & $\begin{array}{l}1 \mathrm{vs} 2=.163 \\
1 \mathrm{vs} 3=.000 \\
2 \mathrm{vs} 3=.376\end{array}$ \\
\hline $\mathrm{HDL}^{*}(\mathrm{mg} / \mathrm{dl})$ & $38.24 \pm 1.46$ & $35.72 \pm 1.55$ & $41.99 \pm 1.10$ & $\begin{array}{l}1 \mathrm{vs} 2=.712 \\
1 \mathrm{vs} 3=.123 \\
2 \mathrm{vs} 3=.004\end{array}$ \\
\hline $\mathrm{TG}^{*}(\mathrm{mg} / \mathrm{dl})$ & $114.22 \pm 7.94$ & $120.99 \pm 8.42$ & $132.76 \pm 5.99$ & $\begin{array}{c}1 \mathrm{vs} 2=1.000 \\
1 \mathrm{vs} 3=.190 \\
2 \mathrm{vs} 3=.806\end{array}$ \\
\hline $\mathrm{R} \mathrm{CIMT}^{*}(\mathrm{~mm})$ & $0.55 \pm 0.01$ & $0.55 \pm 0.02$ & $0.48 \pm 0.01$ & $\begin{array}{c}1 \mathrm{vs} 2=1.000 \\
1 \mathrm{vs} 3=.001 \\
2 \mathrm{vs} 3=.001\end{array}$ \\
\hline L CIMT*(mm) & $0.58 \pm 0.02$ & $0.56 \pm 0.02$ & $0.48 \pm 0.01$ & $\begin{array}{c}1 \mathrm{vs} 2=1.000 \\
1 \mathrm{vs} 3=.000 \\
2 \mathrm{vs} 3=.000\end{array}$ \\
\hline Average CIMT* $*(\mathrm{~mm})$ & $0.55 \pm 0.01$ & $0.56 \pm 0.02$ & $0.48 \pm 0.01$ & $\begin{array}{c}1 \mathrm{vs} 2=1.000 \\
1 \mathrm{vs} 3=.000 \\
2 \mathrm{vs} 3=.000\end{array}$ \\
\hline Waist circumference $*(\mathrm{~cm})$ & $83.69 \pm 1.50$ & $87.78 \pm 1.60$ & $81.58 \pm 1.13$ & $\begin{array}{l}1 \mathrm{vs} 2=.191 \\
1 \mathrm{vs} 3=.783 \\
2 \mathrm{vs} 3=.007\end{array}$ \\
\hline $\begin{array}{c}\text { Subjects with Graying of } \\
\text { hair (n) }\end{array}$ & 28 & 46 & 33 & $\begin{array}{l}1 \mathrm{vs} 2=0.000 \\
1 \mathrm{vs} 3=0.031 \\
2 \mathrm{vs} 3=0.000\end{array}$ \\
\hline
\end{tabular}

*- Adjusted for age, $\mathrm{p}$ value significant at $<0.05$

$\mathrm{CAD}=$ Coronary artery disease, $\mathrm{DBP}=$ Diastolic blood pressure, $\mathrm{FBG}=$ Fasting blood glucose, $\mathrm{HDL}=$ High-density lipoprotein, $\mathrm{HT}=$ Hypertension, $\mathrm{LDL}=$ Low-density lipoprotein, $\mathrm{PPBG}=$ Post prandial blood glucose, $\mathrm{SBP}=\mathrm{Systolic}$ blood pressure, $\mathrm{TC}=$ Total cholesterol, $\mathrm{TG}=$ Triglycerides, $\mathrm{CIMT}=$ Carotid intima media thickness 
The carotid intima media thickness of right, left and common carotid artery in smokers as well as non CAD smokers with CAD (Group I and II) was significantly higher than the control group (Group III).

Dyslipidemia and blood pressure were also significantly higher in group I and II as compared to group III.

When the groups were compared for graying of hair, it was found that the group II (i.e. smokers and $\mathrm{CAD}$ ) had maximum incidence of graying which was significantly higher than the control as well as smoker group. However, the smokers also had a significantly higher proportion of graying than the control group.

Table 2 shows the prediction of association of CAD in the study population as calculated by multiple logistic regression analysis. The presence of premature graying of hair was associated a 3.24 times increased risk of CAD.

Table 2: Prediction of association of CAD in study population of young smokers with various risk factors using multiple logistic regression analysis

\begin{tabular}{|c|c|c|}
\hline $\begin{array}{l}\text { Independent } \\
\text { variables }\end{array}$ & $\begin{array}{l}\text { Odds Ratio (95\% } \\
\text { CI) }\end{array}$ & $\dagger \mathbf{p}$ \\
\hline Age, (years) & $1.10(1.03-1.17)$ & 0.002 \\
\hline $\mathrm{HT}$ & $1.94(0.86-4.38)$ & 0.108 \\
\hline DM & $1.73(0.56-5.33)$ & 0.341 \\
\hline LDL, mg/dl & $1.00(0.99-1.01)$ & 0.703 \\
\hline $\mathrm{HDL}, \mathrm{mg} / \mathrm{dL}$ & $1.94(0.93-0.99)$ & 0.019 \\
\hline Triglyceride, $\mathrm{mg} / \mathrm{dL}$ & $1.00(0.99-1.00)$ & 0.58 \\
\hline Graying of hair & $3.24(1.52-6.88)$ & 0.002 \\
\hline
\end{tabular}

$\dagger$ Logistic regression with Enter method

Dependent variables $=$ Presence of $\mathrm{CAD}$, Independent variables=Age, HT, DM, LDL cholesterol, Triglyceride, Graying of hair

$\mathrm{CAD}=$ coronary artery disease, $\mathrm{CI}=$ confidence interval, $\mathrm{DM}=$ diabetes mellitus,

$\mathrm{HDL}=$ high-density lipoprotein, $\mathrm{HT}=$ hypertension, $\mathrm{LDL}=$ low-density lipoprotein

\section{DISCUSSION}

The present study demonstrated that CIMT measurements and dyslipidemia were significantly different from the control group compared to smokers alone as well as with CAD. When the three groups were compared with respect to graying of hairs, it was found that graying present in the groups of smokers and CAD, was significantly higher than smokers alone as well as controls (Fig 1). It was also found that graying of hairs was independently related to risk of coronary artery disease.

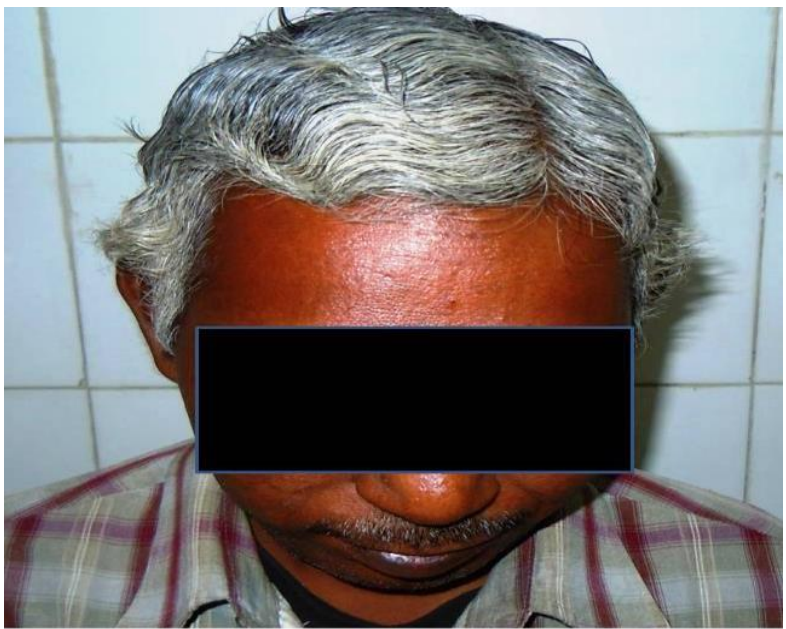

Figure 1: A 42 years old man, chronic smoker and suffered acute coronary event. Note is made of premature graying of hair

The molecular and cellular mechanism for loss of pigmentation of hair includes attenuation of enzymes involved in melanogenesis, impaired DNA repair, loss of telomerase and antioxidant mechanisms (17-22). Atherosclerosis includes oxidant stress, androgens, inflammatory process and senescence of functioning cells. Thus, atherosclerosis and graying of hair share a similar mechanism. Apart from various changes, smoking also produces typical facial changes of premature ageing, premature graying of hair and wrinkles. The incidence of atherosclerotic disease increases with age as is the case with graying of hair. The mammalian hair follicle contains numerous stem cells. These cells produce melanocytes, which give hair its color. The death or dysfunction of the melanocyte stem cells causes the onset of graying (23). These stem cells express CD34 just as the vascular system (24). Today, it is known that cardiovascular risk factors, especially in combination, cause premature atherosclerosis. Similar to their effects on endothelium and circulating progenitor stem cells they may lead to premature and intense hair graying by possible interactions on follicular epithelium and resident stem cells $(24,25)$. 
Our study is also in concurrence with a recent literature showing coronary atherosclerotic burden independently related to hair-graying score. In addition, hair-graying intensity was also associated with age, hyperlipidemia and family history of CAD and creatinine levels (9).

The present study has a few limitations as it was a retrospective study done only in males. The study did not take into account the effect of amount of smoking and degree of dyslipidemia and diabetes. The sample size was also small. Despite these limitations, our study explored the possibility of graying of hair as an independent marker of CAD especially in young smoker population.

In conclusion, the present study disclosed an association between premature graying of hair and development of CAD in smokers as well as nonsmokers. The study postulates that the presence of cutaneous clinical markers like premature graying of hair can be used as preliminary evidence by clinicians for classifying patients at risk for premature CAD especially in smokers. This important sign can be used as a tool for persuading the smokers to quit smoking at the earliest opportunity. Further, a prospective study can be planned to devise a scoring system specific for Indian patients at higher risk for young CAD.

\section{REFERENCES}

1. Arck PC, Overall R, Spatz K, et al. Towards a "free radical theory of graying": melanocyte apoptosis in the aging human hair follicle is an indicator of oxidative stress induced tissue damage. FASEB J, 2006; 20: 1567-1569.

2. Wood JM, Decker H, Hartmann $H$, et al. Senile hair graying: H202-mediated oxidative stress affects human hair color by blunting methionine sulfoxide repair. FASEB J, 2009; 23: 2065-2075.

3. Inomata K, Aoto T, Binh NT, et al. Genotoxic stress abrogates renewal of melanocyte stem cells by triggering their differentiation. Cell, 2009;137:1088-1099.

4. Dai YX, Zhang SY, Tian R, Chen LF, Zhu WL. Clinical manifestations of young and aged patients with coronary artery disease. Zhonghua Xin Xue Guan Bing Za Zhi, 2008; 36: 586-9.
5. Eisenstein I, Edelstein J. Gray hair in black males a possible risk factor in coronary artery disease. Angiology, 1982; 33: 652-4.

6. Gould L, Reddy CV, Oh KC, Kim SG, Becker W. Premature hair graying: a probable coronary risk factor. Angiology, 1978; 29: 800-3.

7. Dwivedi S, Agarwal MP, Singh S. Excessive smoking associated with premature ageing, angina and concentric left ventricular hypertrophy. South Asian J Preventive Cardiology, 1997; 1: 138-139.

8. Dwivedi S, Aggarwal A. Coronary Artery Disease in Young - an Indian Perspective. In Clincal Medicine Update - 2007. Ed. - GL Awasthi. Indian Association of Clinical Medicine, Agra, India. pg 79-97.

9. Kocaman SA, Cetin M, Durakoglugil ME, et al. The degree of premature hair graying as an independent risk marker for coronary artery disease: a predictor of biological age rather than chronological age. Anadolu Kardiyol Derg, 2012; 12:457-63.

10. Rose GA, Blackburn H. Cardiovascular survey methods. In: WHO Monograph Series No. 58. Geneva: World Health Organization; 1982.

11. National High Blood Pressure Education Program. The Seventh Report of the Joint National Committee on Prevention, Detection, Evaluation and treatment of High Blood Pressure. Arch Intern Med, 2003; 157: 24132446.

12. EcoSante. Tobacco consumption in grams per capita. (Accessed December 18, 2008, at http://www.ecosante.fr/OCDEENG/813010.ht ml.).

13. Expert panel on Detection Evaluation and treatment of high blood cholesterol in adults. Executive Summary of the third report of the National Cholesterol Education Program (NCEP) Expert Panel on Detection, Evaluation and Treatment of high blood cholesterol in adults (Adult treatment Panel III). JAMA, 2001; 285: 2486 - 97.

14. Follow-up Report on the Diagnosis of Diabetes Mellitus. The Expert Committee on the diagnosis and classification of diabetes mellitus. Diabetes Care, 2005; 26: 3160-3167.

15. Alberti KG, Zimmet P, Shaw J. IDF Epidemiology Task Force Consensus Group. 
The metabolic syndrome - a new worldwide definition. Lancet, 2005; 366:1059-62.

16. Pignoli P, Tremoli E, Poli A, Oreste P, Paoletti R. Intimal plus medial thickness of arterial wall: A direct measurement with ultrasound imaging. Circulation, 1986; 74: 1399-1406.

17. Frank ST. Aural sign of coronary - artery disease. N Engl J Med 1973; 289: 327-8.

18. Cotton SG, Nixon JM, Carpenter RG, Evans DW. Factors discriminating men with coronary heart disease from healthy controls. Br Heart J, 1972; 34: 458-64.

19. Lichstein E, Chadda KD, Naik D, Gupta PK. Diagonal ear-lobe crease: prevalence and implications as a coronary risk factor. $N \mathrm{Engl}$ J Med, 1974; 290: 615-6.

20. Cooke NT. Male pattern alopecia and coronary artery disease in men. $B r \quad J$ Dermatol, 1979; 101: 455-8.
21. Kirham N, Murrels T, Melcher DH, Morrison EA. Diagonal earlobe creases and fatal cardiovascular disease: a necropsy study. $\mathrm{Br}$ Heart J, 1989;61:361-4.

22. Trevisan M, Farinaro E, Krogh V, Jossa F, Giumetti D, Fusco G, et al. Baldness and coronary heart disease risk factors. J Clin Epidemiol, 1993; 46: 1213-8.

23. Nishimura EK, Granter SR, Fisher DE. Mechanisms of hair graying: incomplete melanocyte stem cell maintenance in the niche. Science, 2005; 307: 720-4.

24. Misago N, Toda S, Narisawa Y. CD34 expression in human hair follicles and tricholemmoma: a comprehensive study. $J$ Cutan Pathol, 2011; 38: 609-15.

25. Krause K, Foitzik K. Biology of the hair follicle: the basics. Semin Cutan Med Surg, 2006;25:2-10. 